Reply

\title{
Reply: "Vitamin D Supplementation in Influenza and COVID-19 Infections. Comment on: Evidence That Vitamin D Supplementation Could Reduce Risk of Influenza and COVID-19 Infections and Deaths Nutrients 2020, 12(4), 988"
}

\author{
William B. Grant ${ }^{1, *}$, , Carole A. Baggerly ${ }^{2}$ and Henry Lahore ${ }^{3}$ \\ 1 Sunlight, Nutrition, and Health Research Center, P.O. Box 641603, San Francisco, CA 94164-1603, USA \\ 2 GrassrootsHealth, Encinitas, CA 95101, USA; carole@grassrootshealth.org \\ 32289 Highland Loop, Port Townsend, WA 98368, USA; hlahore@gmail.com \\ * Correspondence: wbgrant@infionline.net; Tel.: +1-415-409-1980
}

Received: 20 April 2020; Accepted: 8 May 2020; Published: 1 June 2020

Keywords: African Americans; COVID-19; C-reactive protein; hemoglobin; influenza; randomized controlled trials; respiratory tract infections; vitamin $\mathrm{D}$; vitamin $\mathrm{D}_{2}$; vitamin $\mathrm{D}_{3}$

We thank Dr. Hasan for the comments [1] on our review [2] and for providing us the opportunity to extend the discussion regarding the role of vitamin $\mathrm{D}$ in reducing the risk of respiratory tract infections.

Dr. Hasan's first point: "However, we are rather concerned with authors' recommendation that people at risk of COVID-19 should consider 'taking 10,000 IU/d of vitamin $\mathrm{D}_{3}$ for a few weeks to rapidly raise $25(\mathrm{OH}) \mathrm{D}$ concentrations, followed by $5000 \mathrm{IU} / \mathrm{d}$ to reduce the risk of infection'. We believe that authors' recommendation of using a high dose of vitamin D supplementation is inappropriate as there is no robust clinical evidence to support such claims." Our recommendation was based on reaching a serum 25-hydroxyvitamin $\mathrm{D}[25(\mathrm{OH}) \mathrm{D}]$ concentration between 40 and $60 \mathrm{ng} / \mathrm{mL}$ in advance of the winter viral respiratory tract infection (RTI) season. According to Figure 1 in an article by Heaney [3], when starting at a level of around $20 \mathrm{ng} / \mathrm{mL}$ it takes about 35 days to reach $60 \mathrm{ng} / \mathrm{mL}$ with 10,000 IU/d and 85 days with $4000 \mathrm{IU} / \mathrm{d}$. A randomized controlled trial (RCT) published in 2015 showed that after a single dose of 250,000 IU of vitamin $\mathrm{D}_{3}$ given to healthy volunteers between the ages of 18 and 65 years with baseline serum levels of $<17 \mathrm{ng} / \mathrm{m}$, serum 25(OH)D concentrations at five days increased to an average of $41 \mathrm{ng} / \mathrm{mL}$ [4]. There were no adverse effects. However, after 90 days, $25(\mathrm{OH}) \mathrm{D}$ concentrations were back to near baseline values. In the preprint of the first submitted version of our review [5], we discussed the results of reported influenza-like illness (ILI) with respect to serum 25(OH)D concentrations for GrassrootsHealth participants (this information was omitted from the published review since it should go through the peer review process independent of its inclusion in a review.) Table 1 reports that, compared to $[25(\mathrm{OH}) \mathrm{D}]$ of $<20 \mathrm{ng} / \mathrm{mL}$, the adjusted odds ratio for ILI for $40-49 \mathrm{ng} / \mathrm{mL}, 50-59 \mathrm{ng} / \mathrm{mL}$, and $\geq 60 \mathrm{ng} / \mathrm{mL}$ were $0.04,0.02$, and 0.03 , respectively. While this finding was not related to COVID-19, there are indications that viral RTIs have similar etiologies. Those who are concerned about exposure to the COVID-19 virus or who have symptoms of COVID-19 infection might benefit from a much larger dose, although clinical trials need to be performed.

Very recently, a preprint reported severity of COVID-19 infections with respect to 25(OH)D concentration in three Asian countries [6]. Out of 49 patients with mild symptoms, 47 had serum 25(OH)D concentrations of $>30 \mathrm{ng} / \mathrm{mL}$ compared with only four of 59 with ordinary symptoms, two of 56 severe patients, and two of 48 critical patients. The mean serum $25(\mathrm{OH}) \mathrm{D}$ concentrations for mild, ordinary, severe, and critical patients were $31,27,21$, and $17 \mathrm{ng} / \mathrm{mL}$, respectively. 
Results of a study of seroprevalence for COVID-19 in Santa Clara County, California were reported in a preprint [7], with A total of 3330 people included; 50 people were found to have antibodies for COVID-19. After adjusting the data to correspond to the demographic characteristics of the county, the seroprevalence to COVID-19 was estimated at between $2.49 \%$ and $4.16 \%$, with uncertainty bounds ranging from $1.80 \%$ up to $5.70 \%$. This estimate translates to 48,000 to 81,000 people in the county, which is 50 to 80 times the 956 people that were identified by April 1,2020. It should be noted that this study has not been peer reviewed and may have some methodological issues to address. We think it likely that many have contracted COVID-19 with minimal or no symptoms. Supporting this idea, several coronaviruses exist that result in minor colds in the January-February timeframe, as found from a study of children crossing the Southern China-Hong Kong border [8].

These two studies support our suggestion of 40 to $60 \mathrm{ng} / \mathrm{mL}$, since one study presented COVID-19 infection with $25(\mathrm{OH}) \mathrm{D}$ concentrations of $>30 \mathrm{ng} / \mathrm{mL}$ and the other found that many people were infected without symptoms. Elderly people with chronic diseases are very likely to have low $25(\mathrm{OH}) \mathrm{D}$ concentrations, as discussed in our review [2]. However, further studies are required to better determine the threshold for protection against COVID-19 infection with symptoms.

As is well known, COVID-19 patients in critical condition often require a ventilator to help supply oxygen to their blood. A meta-analysis of laboratory findings of clinical characteristics for COVID-19 patients found that the pooled frequency of anemia from two studies was $44 \%$ (95\% CI, 30\%-58\%), while the pooled frequency for high C-reactive protein (CRP) from eight studies was $72 \%$ ( $95 \%$ CI, 54\%-85\%) [9]. A study conducted in Egypt found that serum 25(OH)D concentration was inversely correlated with the degree of severity of acute lower RTIs $(r=0.80)$ in hospitalized infants with a mean age of $11 \pm 3$ months [10]. In addition, hemoglobin level was also highly correlated with serum $25(\mathrm{OH}) \mathrm{D}$ concentration $(r=0.71)$, with the mean concentration ranging from $9 \mathrm{ng} / \mathrm{dL}$ for $6 \mathrm{ng} / \mathrm{mL}$ 25(OH)D to $14 \mathrm{ng} / \mathrm{dL}$ for $50 \mathrm{ng} / \mathrm{mL} 25(\mathrm{OH}) \mathrm{D}$.

While low-dose vitamin D supplementation was not found to increase hemoglobin concentration in short-term studies [11], high-dose vitamin D supplementation was. A clinical trial involving 30 mechanically ventilated, critically ill adults were assigned to three groups to receive a placebo, 250,000 IU vitamin $\mathrm{D}_{3}$, or 500,000 IU vitamin $\mathrm{D}_{3}$ total during a five-day periods [12]. Mean baseline hemoglobin concentration was between 8.5 and $10.5 \mathrm{~g} / \mathrm{dL}$ for the three groups. Hemoglobin concentration increased significantly only for the $500,000 \mathrm{IU}$ vitamin $\mathrm{D}_{3}$ group, who experienced a $2 \mathrm{~g} / \mathrm{dL}$ increase in four weeks. However, a phase 3 RCT involving 1078 critically ill vitamin D-deficient patients, with those in the treatment arm given $540,000 \mathrm{IU}$ vitamin $\mathrm{D}_{3}$ supplementation within $12 \mathrm{~h}$ of admission to an intensive care unit, found no significant benefit in terms of 90 -day mortality rate $(P=0.26)$ or with respect to secondary clinical, physiological, or safety end-points [13].

A cross-sectional study using data from the USA's National Health and Nutrition Examination Surveys data found that CRP varied from $222(95 \%$ CI, 205-241) $\mathrm{mcg} / \mathrm{dL}$ for a $25(\mathrm{OH}) \mathrm{D}$ concentration of $<12 \mathrm{ng} / \mathrm{mL}$ to 199 (179-201) $\mathrm{mcg} / \mathrm{dL}$ for $>30 \mathrm{ng} / \mathrm{mL} 25(\mathrm{OH}) \mathrm{D}$ [14].

Thus, by analogy, vitamin D deficiency appears to be a very important risk factor for severe COVID-19 infection.

Dr. Hasan's second point: “The authors have conveniently ignored the results of some key clinical studies evaluating the effectiveness of vitamin D supplementation in reducing the risk of developing respiratory tract infections (RTIs)." The meta-analysis of 15 RCTs on the effectiveness of vitamin D supplementation on risk of RTIs by Gysin et al. [15] had a serious flaw: the evaluations were made based on vitamin D dose vs. placebo, not serum 25(OH)D concentration. Vitamin D does not have a direct bearing on disease risk; it is $25(\mathrm{OH}) \mathrm{D}$ concentration that was found to be associated with disease risk. Inspection of the RCTs used in their analysis in Figure 3 presented some with very low baselines with significantly reduced risk of RTIs and very low vitamin D doses, while others with high baseline 25(OH)D concentrations and high vitamin D doses exhibited no effect. Heaney's guidelines for RCTs for nutrients such as vitamin D were discussed in our review [16], the most important factor being that 
they be based on $25(\mathrm{OH}) \mathrm{D}$ concentration, both baseline and achieved, and that sufficient vitamin $\mathrm{D}_{3}$ be given.

Regarding the individual participant data meta-analysis of RTI in vitamin D RCTs [17], there were few participants who achieved a $25(\mathrm{OH}) \mathrm{D}$ concentration of $>40 \mathrm{ng} / \mathrm{mL}$, so they could not adequately assess the impact of high $25(\mathrm{OH}) \mathrm{D}$ concentration. We noted that a study in Connecticut found $38 \mathrm{ng} / \mathrm{mL}$ as the threshold for a significantly lower risk of community-based pneumonia [18].

Dr. Hasan's third point: "Although high dose vitamin D3 was not found to increase the risk of kidney stone or hypercalcemia, it is not devoid of side effects as a randomized clinical trial only observed significant lower radial bone and tibial bone mineral density with 3-year-treatment of vitamin D at a dose of 10,000 IU/d". Regarding the possible adverse effects of high-dose vitamin D supplementation, we read the article by Burt et al. [19]. As mentioned in the comment, the only adverse finding was a reduction (3.5\%) in bone mass density. However, bone mass density does not equate to bone strength, and the reductions in strength measured as failure load were not significant. That was a three-year study, whereas we are suggesting a strategy for the winter RTI season. We also note that all pharmaceutical drugs have adverse side effects. If high-dose vitamin $\mathrm{D}$ is considered a drug, it differs from pharmaceutical drugs in that it has many side benefits [20].

Dr. Hasan's fourth point: "Given the possible negative impact on bone mineral density with high dose vitamin D3, it is probably wise to wait for the results of ongoing clinical trials that are registered to explore the relationship between vitamin D and COVID-19." We agree that RCTs should be conducted to evaluate the role of vitamin D in preventing and treating COVID-19 infection. However, we strongly disagree that vitamin D supplementation should be held in abeyance for prevention until such RCTs are completed and reported. Those at highest risk of infection due to having chronic disease, low 25(OH)D status, and/or being in frequent contact with others likely to be infected should be taking vitamin D. As noted, there is mounting evidence that vitamin D can reduce the risk and severity of RTIs, including that the mechanisms are known, that there are many health benefits of higher $25(\mathrm{OH}) \mathrm{D}$ concentrations, and that there are very few adverse effects of vitamin $\mathrm{D}_{3}$ supplementation. Vitamin D has demonstrated effectiveness in reducing the risk of overall cancer incidence and death, as well as the risk of progressing from pre-diabetes to diabetes in secondary results of major vitamin D RCTs [21]. Thus, there is much to gain and little to lose by taking vitamin D supplements now for COVID-19 prevention. RCTs should be conducted for treatment to explore at which stages of infection what baseline $25(\mathrm{OH}) \mathrm{D}$ concentrations, vitamin D doses, and achieved 25(OH)D concentrations are associated with benefits and adverse effects, if any.

Dr. Hasan's fifth point questioned our statement: "A clinical trial involving postmenopausal women living on Long Island, NY with mean baseline $25(\mathrm{OH}) \mathrm{D}$ concentration $19 \pm 8 \mathrm{ng} / \mathrm{mL}$ found that supplementation with $2000 \mathrm{IU} / \mathrm{d}$ resulted in significantly fewer upper respiratory tract infections, including influenza, than a placebo or supplementation with $800 \mathrm{IU} / \mathrm{d}$ [22]." In this trial, 104 participants took a placebo for three years and suffered from 29 RTIs in total, 104 took $800 \mathrm{IU} / \mathrm{d}$ vitamin $\mathrm{D}_{3}$ for two years and suffered 8 RTIs, and 104 took $2000 \mathrm{IU} / \mathrm{d}$ vitamin $\mathrm{D}_{3}$ and one RTI was recorded. The odds ratio for $800 \mathrm{IU} / \mathrm{d}$ vs. placebo was 0.39 (95\% confidence interval, $0.17-0.87, P=0.02)$, while that for $2000 \mathrm{IU} / \mathrm{d}$ vs. placebo was $0.09(0.01-0.50, P=0.02)$.

We use this opportunity to respond to two important comments by other readers of our review. One questioned why we did not indicate that vitamin $\mathrm{D}_{3}$ (cholecalciferol) be used rather than vitamin $\mathrm{D}_{2}$ (ergocalciferol), the answer being that, in some countries, the only high-dose vitamin $\mathrm{D}$ is ergocalciferol. However, cholecalciferol is a better choice, in part since it is the type of vitamin $D$ produced in the skin through ultraviolet B irradiation of 7-dehydrocholesterol followed by a thermal reaction. After publication of our review, an article was published reporting the effects of vitamin $\mathrm{D}$ on gene expression of rat oligodendrocyte precursor cells. The study found that vitamin $\mathrm{D}_{3}$ influenced 1272 genes in $24 \mathrm{~h}$ compared to only 574 for vitamin D [23]. Most of the effects of vitamin D are through the hormonal metabolite 1,25-dihydroxyvitamin $\mathrm{D}$, which activates vitamin $\mathrm{D}$ receptors bound to chromosomes, thereby affecting the expression of many genes. 
The second question was why we did not point out that African Americans (AAs) have a much higher risk of COVID-19 infection and death than white Americans. At the time we submitted our manuscript, the data comparing AA COVID-19 infection and mortality rates were not available. In addition, there are a number of other reasons why AAs have higher COVID-19 rates, including that they have higher chronic disease rates than white Americans [24].

People with chronic diseases generally have low 25(OH)D concentrations (see Table 2 in [2]). Now, however, it is well-known that AAs have much higher COVID-19 infection and mortality rates [25]. Based on the National Health and Nutrition Examination Survey (NHANES) 2001-2010, the prevalence of serum $25(\mathrm{OH}) \mathrm{D}$ concentrations $<20 \mathrm{ng} / \mathrm{mL}$ was $72 \%$ for non-Hispanic blacks (NHBs), $43 \%$ for Hispanics, and 19\% for non-Hispanic whites, with the prevalence of $<10 \mathrm{ng} / \mathrm{mL}$ being $17 \%$ in NHBs [26]. Of all the risk factors AAs have for becoming infected with COVID-19, raising serum $25(\mathrm{OH}) \mathrm{D}$ concentrations is the easiest one to counter.

Funding: No funding was received for this study.

Conflicts of Interest: W.B.G. receives funding from Bio-Tech Pharmacal, Inc. (Fayetteville, AR). GrassrootsHealth works with various supplement suppliers to test the efficacy of their products in various custom projects. These suppliers may be listed as 'Sponsors' of GrassrootsHealth. H.L. has no conflicts of interest to declare. VitaminDWiki.com receives funding from Bio-Tech Pharmacal, Inc.

\section{References}

1. Kow, C.S.; Hadi, M.A.; Hasan, S.S. Vitamin D Supplementation in Influenza and COVID-19 Infections Comment on: "Evidence that Vitamin D Supplementation Could Reduce Risk of Influenza and COVID-19 Infections and Deaths". Nutrients 2020, 12, 988.

2. Grant, W.B.; Lahore, H.; McDonnell, S.L.; Baggerly, C.A.; French, C.B.; Aliano, J.L.; Bhattoa, H.P. Evidence that Vitamin D Supplementation Could Reduce Risk of Influenza and COVID-19 Infections and Deaths. Nutrients 2020, 12, 988. [CrossRef] [PubMed]

3. Heaney, R.P.; Davies, K.M.; Chen, T.C.; Holick, M.F.; Barger-Lux, M.J. Human serum 25-hydroxycholecalciferol response to extended oral dosing with cholecalciferol. Am. J. Clin. Nutr. 2003, 77, 204-210. [CrossRef] [PubMed]

4. Kearns, M.D.; Binongo, J.N.; Watson, D.; Alvarez, J.A.; Lodin, D.; Ziegler, T.R.; Tangpricha, V. The effect of a single, large bolus of vitamin $\mathrm{D}$ in healthy adults over the winter and following year: A randomized, double-blind, placebo-controlled trial. Eur. J. Clin. Nutr. 2015, 69, 193-197. [CrossRef]

5. Grant, W.B.; Lahore, H.; McDonnell, S.L.; Baggerly, C.A.; French, C.B.; Aliano, J.L.; Bhattoa, H.P. Vitamin D Supplementation Could Prevent and Treat Influenza, Coronavirus, and Pneumonia Infections. Available online: https://www.preprints.org/manuscript/202003.200235/v202001 (accessed on 15 March 2020).

6. Alipio, M.M. Vitamin D Supplementation Could Possibly Improve Clinical Outcomes of Patients Infected with Coronavirus-2019 (COVID-2019). SSRN Electron. J. 2020. [CrossRef]

7. Bendavid, E.; Mjulaney, B.; Sood, N.; Shah, S.; Ling, E.; Bromlsy-Dulfano, R.; Lai, C.; Weissberg, Z.; Saavedra-Walker, R.; Tedrow, J.; et al. COVID-19 Antibody Seroprevalence in Santa Clara County, California. medRxiv 2020, 17. [CrossRef]

8. Liu, P.; Shi, L.; Zhang, W.; He, J.; Liu, C.; Zhao, C.; Kong, S.K.; Loo, J.F.C.; Gu, D.; Hu, L. Prevalence and genetic diversity analysis of human coronaviruses among cross-border children. Virol. J. 2017, 14, 230. [CrossRef]

9. Nasiri, M.J.; Haddadi, S.; Tahvildari, A.; Farsi, Y.; Arabi, M.; Hasanzadeh, S.; Jamshidi, P.; Murthi, M.; Misrsaeidi, M.S. COVID-19 clinical characteristics, and sex-specific risk of mortality: Systematic Review and Meta-analysis. medRxiv 26 March 2020. [CrossRef]

10. El Sakka, A.S.; Imam, S.S.; Amer, H.A.; Moustafa, S.A. Vitamin D deficiency and low hemoglobinlevel as risk factors for severity of acute lowerrespiratory tract infections in Egyptian children: A case-control study. Egyptian Pediatric Association Gazette 2014, 61, 1-7. [CrossRef]

11. Arabi, S.M.; Ranjbar, G.; Bahrami, L.S.; Vafa, M.; Norouzy, A. The effect of vitamin D supplementation on hemoglobin concentration: A systematic review and meta-analysis. Nutr. J. 2020, 19, 11. [CrossRef] 
12. Smith, E.M.; Jones, J.L.; Han, J.E.; Alvarez, J.A.; Sloan, J.H.; Konrad, R.J.; Zughaier, S.M.; Martin, G.S.; Ziegler, T.R.; Tangpricha, V. High-Dose Vitamin D3 Administration Is Associated with Increases in Hemoglobin Concentrations in Mechanically Ventilated Critically Ill Adults: A Pilot Double-Blind, Randomized, Placebo-Controlled Trial. J. Parenter. Enteral. Nutr. 2018, 42, 87-94. [CrossRef] [PubMed]

13. National Heart, L.; Blood Institute, P.C.T.N.; Ginde, A.A.; Brower, R.G.; Caterino, J.M.; Finck, L.; Banner-Goodspeed, V.M.; Grissom, C.K.; Hayden, D.; Hough, C.L.; et al. Early High-Dose Vitamin D3 for Critically Ill, Vitamin D-Deficient Patients. N. Engl. J. Med. 2019, 381, 2529-2540. [CrossRef]

14. Ganji, V.; Tangpricha, V.; Zhang, X. Serum Vitamin D Concentration $>/=75 \mathrm{nmol} / \mathrm{L}$ Is Related to Decreased Cardiometabolic and Inflammatory Biomarkers, Metabolic Syndrome, and Diabetes; and Increased Cardiorespiratory Fitness in US Adults. Nutrients 2020, 12, 730. [CrossRef] [PubMed]

15. Vuichard Gysin, D.; Dao, D.; Gysin, C.M.; Lytvyn, L.; Loeb, M. Effect of Vitamin D3 Supplementation on Respiratory Tract Infections in Healthy Individuals: A Systematic Review and Meta-Analysis of Randomized Controlled Trials. PLoS ONE 2016, 11, e0162996. [CrossRef] [PubMed]

16. Heaney, R.P. Guidelines for optimizing design and analysis of clinical studies of nutrient effects. Nutr. Rev. 2014, 72, 48-54. [CrossRef] [PubMed]

17. Martineau, A.R.; Jolliffe, D.A.; Hooper, R.L.; Greenberg, L.; Aloia, J.F.; Bergman, P.; Dubnov-Raz, G.; Esposito, S.; Ganmaa, D.; Ginde, A.A.; et al. Vitamin D supplementation to prevent acute respiratory tract infections: Systematic review and meta-analysis of individual participant data. BMJ 2017, 356, i6583. [CrossRef] [PubMed]

18. Sabetta, J.R.; DePetrillo, P.; Cipriani, R.J.; Smardin, J.; Burns, L.A.; Landry, M.L. Serum 25-hydroxyvitamin $\mathrm{d}$ and the incidence of acute viral respiratory tract infections in healthy adults. PLOS ONE 2010, 5, e11088. [CrossRef]

19. Burt, L.A.; Billington, E.O.; Rose, M.S.; Raymond, D.A.; Hanley, D.A.; Boyd, S.K. Effect of High-Dose Vitamin D Supplementation on Volumetric Bone Density and Bone Strength: A Randomized Clinical Trial. JAMA 2019, 322, 736-745. [CrossRef] [PubMed]

20. Wimalawansa, S.J. Non-musculoskeletal benefits of vitamin D. J. Steroid Biochem. Mol. Biol. 2018, 175, 60-81. [CrossRef]

21. Grant, W.B.; Boucher, B.J. Why Secondary Analyses in Vitamin D Clinical Trials Are Important and How to Improve Vitamin D Clinical Trial Outcome Analyses-A Comment on “Extra-Skeletal Effects of Vitamin D, Nutrients 2019, 11, 1460" . Nutrients 2019, 11, 2182. [CrossRef]

22. Aloia, J.F.; Li-Ng, M. Re: Epidemic influenza and vitamin D. Epidemiol. Infect. 2007, 135, 1095-1096; author reply 1097-1098. [CrossRef] [PubMed]

23. Mengozzi, M.; Hesketh, A.; Bucca, G.; Ghezzi, P.; Smith, C.P. Vitamins D3 and D2 have marked but different global effects on gene expression in a rat oligodendrocyte precursor cell line. Mol. Med. 2020, 26, 32. [CrossRef] [PubMed]

24. Cunningham, T.J.; Croft, J.B.; Liu, Y.; Lu, H.; Eke, P.I.; Giles, W.H. Vital Signs: Racial Disparities in Age-Specific Mortality among Blacks or African Americans-United States, 1999-2015. Morb. Mortal. Wkly. Rep. 2017, 66, 444-456. [CrossRef] [PubMed]

25. Garg, S.; Kim, L.; Whitaker, M.; O’Halloran, A.; Cummings, C.; Holstein, R.; Prill, M.; Chai, S.J.; Kirley, P.D.; Alden, N.B.; et al. Hospitalization Rates and Characteristics of Patients Hospitalized with Laboratory-Confirmed Coronavirus Disease 2019_COVID-NET, 14 States, March 1-30, 2020. Morb. Mortal. Wkly. Rep. 2020, 69, 7. [CrossRef]

26. Liu, X.; Baylin, A.; Levy, P.D. Vitamin D deficiency and insufficiency among US adults: Prevalence, predictors and clinical implications. Br. J. Nutr. 2018, 119, 928-936. [CrossRef]

C 2020 by the authors. Licensee MDPI, Basel, Switzerland. This article is an open access article distributed under the terms and conditions of the Creative Commons Attribution (CC BY) license (http://creativecommons.org/licenses/by/4.0/). 